\title{
A Proposed Model of Antecedents and Outcomes of Brand Orientation for Nonprofit Sector
}

\author{
Fahri Apaydın \\ Faculty of Economics and Administrative Sciences, Yalova University \\ Safranyolu, 77100, Yalova, Turkey \\ Tel: 90-216-814-9932 E-mail: apaydin@yalova.edu.tr
}

Received: July 25, $2011 \quad$ Accepted: August 10, $2011 \quad$ doi:10.5539/ass.v7n9p194

\begin{abstract}
Most literature focuses on the branding in the profit sector, while few efforts have been spent on studies in the nonprofit sector which has been in the rise in the last decades and constitutes a remarkable percentage of the economy in many developed countries. Nonprofit organizations are in essence a kind of an indicator of how developed a country is, so it might be accepted that in underdeveloped countries and developing countries they are not well established yet, so analyzing the well established nonprofit organizations will also usher the ones which are at still birth age. An issue which should be analyzed about nonprofit organizations is the application of a significant marketing concept of brand orientation. The proposed research aims to highlight the importance of branding and brand orientation for nonprofit organizations and to bring to surface the antecedents and the outcomes of being brand oriented in nonprofit sector. A comprehensive literature review was done and a conceptual model is proposed in this literature review.
\end{abstract}

Keywords: Brand orientation, Nonprofit sector, Outcomes of brand orientation, Antecedents of brand orientation

\section{Introduction}

In many developed countries, nonprofit sector is increasing "its scope of activities and becoming prominent" in the business environment involving in trade activities as well as collecting donations for the needy (Dolnicar $\&$ Randle, 2007; Hankinson, 2000; Wiepking, 2007). As the number of nonprofit organizations (public charities, private foundations, other types of nonprofit organizations, including chambers of commerce, fraternal organizations, and civic leagues) increases, competition in this sector becomes tougher as one may expect. As a result, it becomes even harder to obtain financial resources as well as voluntary contribution. Without doubt, this makes it difficult to realize their mission, which is to contribute to the welfare of the society. Thus, similar to the commercial sector which has developed and built brands as a means of creating and maintaining a point of difference in an increasingly competitive environment, nonprofit organizations are now more apt to become a brand in this sector, believing that brands are significant assets for them which differentiate them from the competitors.

In the literature, it is possible to find various classifications of nonprofit organizations done in different researches. After studying a summary of each organization's goals and activities, following purposive classification which can be used in the researches were done by researchers (Jacobs \& Glass 2002; Ewing \& Napoli, 2005; Balabanis et. al., 1997; Hou, 2009):

1. Social justice organizations, which fight for generalized issues of social concern

2. Cultural organizations, which engage in the fine arts, music, theater, literature, or other cultural activities

3. Social leisure organizations, which exist for explicit social and/or hobby purposes, such as fraternities or bowling leagues

4. Economic organizations, such as trade organizations or chambers of commerce

5. Educational and human service organizations, which engage in research, are affiliated with a school, or provide educational programs 
The main aims of this paper are:

- to highlight the importance of brand orientation for nonprofit organizations

- to determine the antecedents of brand orientation

- to determine outcomes of brand orientation in nonprofit organizations

- to foster managers' awareness of branding in nonprofit organizations

- to contribute to the research field of branding in nonprofit context

Laidler-Kylander \& Simonin (2009) mention that there is a void in the literature about researches related with nonprofit organizations, especially in the area of branding. Thus, this model is believed to help answer the following questions related with nonprofit organizations.

1. How do nonprofit organizations become brand oriented, and what does brand orientation mean for nonprofit organizations?

2. What are the antecedents of brand orientation, and how can performance of nonprofit organizations be measured?

3. Does brand orientation increase the performance results of nonprofit organizations?

4. What are the differences between various categorizes of nonprofit organizations in terms of branding and outcomes of being brand oriented?

5. Which type of nonprofit organizations gets more voluntary contribution and donation?

6. Does the size of nonprofit organization affect its being brand oriented and its receiving more donation?

7. What are the mediating variables that affect the impact of the antecedents on brand orientation?

8 . How does being brand oriented contribute to the mission of nonprofit organizations?

\section{Literature Review}

\subsection{Marketing in Nonprofit Sector}

In spite of the size and importance of the nonprofit sector to all economies, "nonprofit organizations have only recently begun to embrace the marketing concept that for-profit organizations have exploited for years" (Benett and Sargeant, 2005). That nonprofit organizations have begun to develop and apply marketing strategies and activities is not surprising when the challenges facing the industry and organizations today are realized. Some factors such as "worsening economies, a decline in direct donations, a decline in government support" (Hibbert \& Horne, 1995) create challenges in achieving their mission and goals and increase competition for funding and voluntary contribution (Liao, Foreman and Sargeant, 2001). Given the highly competitive environment nonprofit organizations are in, it is obvious that the non-profit sector needs to act more aggressively and creatively in their efforts to attract both "individual and corporate donors, volunteers, sponsors and partners". To accomplish the above mentioned goals, the sector is trying to adopt a wide range of marketing activities and concepts developed in profit sector. Hassay (2009) in his research explored brand community, relationship marketing, nonprofit marketing, charity support behavior integrating the marketing concepts in nonprofit sector. It is possible to reach other researches done examining the application of marketing concepts in the nonprofit sector, though some might raise questions about the relevance of it.

Nonprofit organizations mainly depend on resources they obtain from various bodies within the society, which necessitates strong relationship between the organizations and these bodies (Bennett \& Savani, 2004; Hou et. al., 2009). Marketing science has developed so many successful techniques and methods not only to manage the relationship between the organizations and the customers and suppliers but also communication with the environment. Thus, nonprofit organizations to receive more resource and actualize their mission, increasing the welfare of the society in different respects, should benefit from these techniques and methods. Dolnicar \& Randel (2007) defined main voluntary activities as "admin/clerical/recruitment, coaching/refereeing/judging, befriending/supportive listening counsel, fundraising/sales, preparing/serving food, repairing/maintenance/gardening, management/committee work/co-ordination, personal care/assistance, and teaching/instruction/providing information". Carrying such actions successfully requires developing strong relationships as well as doing communication activities, all of which require satisfactory amount of financial and human resources. 
Substantial differences which are said to exist between nonprofits and for-profits are a reason why the brand orientation concept should be explored in this sector based on scientific researches. Thus, it is highly imperative that these differences be well understood to gain an overall idea to apply brand orientation concept in this sector. Nonprofit organizations differ from for-profit organizations in at least five major areas: "their organizational culture, their human resources, their collaborative rather than competitive approaches, the complexity of their customers, and the importance of mission" (Laidler-Kylander \& Simonin, 2009; Gainer \& Padanyi, 2002). Because of these differences, nonprofit organizations are organized and work distinctly from profit organizations.

\subsection{Branding in Nonprofit Sector}

Of the marketing concepts, branding in the nonprofit organizations is considered to be a significant issue to deal with. Due to the huge amounts of finance nonprofit organizations manage and consume and the proliferating activities they do, researches are interested in the application of marketing concepts in nonprofit sector. Brand perceptions, brand loyalty, brand knowledge, brand differentiation, brand equity, brand awareness, brand proliferation and brand image are the underlying issues about the concept of brand, which has received so much attention in for profit sector (Aaker, 1996; Keller, 2003). It has been posited by many researchers that "building a successful brand can help nonprofit organizations differentiate from the competitors, be held in high esteem, and evoke a connection with target customers" (Wong and Merrilees, 2005).

A strong brand is believed to facilitate its acceptance and gaining support from the society for new services and products for the sake of the society in that "brand name recognition and image of the organization are communicated efficiently by brand names" . Thus, by creating strong brands nonprofit organizations might enjoy the advantage of getting higher support from the society and deliver their services and products to the needy, which will contribute to the achievement of organizational mission. Brand names are "leverages for the organizations" as stakeholders are familiar with them and they represent "established knowledge" in people's minds. To build brands, nonprofit organizations develop and create "favorable associations" about themselves in the "knowledge structure" in the minds of the people. Strong brands facilitate people's judgment about the nonprofit organization in a positive way as they build "links in people's minds about organization with the desirable associations that already exist" (Aaker and Lane, 1990).

It is a priority for nonprofit organization managers to create positive beliefs and favorable attitudes toward the nonprofit organization to develop strong brand names within the society (Aaker and Lane, 1990). Hankinson (2000) explains how brands function and classifies two main functions of brands: "Brands contain functional attributes (what the brand does) and they have symbolic values (what the brand represents)". Aaker (1996) suggests that "brand name, brand awareness, brand loyalty, perceived quality and distinctive brand associations are the important characteristics of strong brand". Therefore, nonprofit organizations should carry out activities supporting and developing to create strong brand names. For consumers, brands exert three major functions: "an information purpose, a risk-reduction purpose, and an image purpose". Thus, they obtain public trust which helps them accomplish their missions successfully. Greater brand trust results in high levels of brand equity (i.e. strong brand), and some nonprofit organizations which are aware of the significance of branding are increasingly being perceived as the "new super brands in the West" (Laidler-Kylander \& Simonin, 2009).

Given the functions of branding mentioned above, it may serve some important purposes for nonprofit organizations as well. Firstly, they improve the resource acquisition potential of nonprofit organizations and have a positive effect on receiving voluntary contribution and donations. Second, positive associations related with nonprofit brand might be developed in the minds of the people, therefore products and services of nonprofit organizations becomes more likely to be accepted by the society and the needy. Furthermore, strong brands also function as a basis to create new programs and services that will serve the needy (Voeth \& Herbst, 2008). As a result, nonprofit organizations might broaden their range of activities, which will contribute to the societies' welfare. Hankinson's (2000) suggestions that the charities (a kind of nonprofit organization) which were committed to the branding took advantage of "charity brand status" might support the relevance of the functions of brands for non-profit sector.

\subsection{Brand Orientation in Nonprofit Sector}

Hankinson (2000) defines brand orientation as "to the extent to which the organization regards itself as a brand". According to a broader definition "brand orientation refers to the extent to which the marketing strategy and activities are focused on the nonprofit brand aiming to reinforce distinctiveness from the other nonprofit organizations and building awareness of the organization". The activities held by the organization reflect how nonprofit organizations approach to branding. Brand oriented organizations carry out activities that will enhance 
the organization's image. "Brand orientation becomes the driving force for brand-oriented organizations that consider branding as a significant issue in all the organizational decisions and directions. It emphasizes the deployment of the marketing mix and human resources to deliver a distinctive brand in the customer's minds" (Wong \& Merrilees, 2005). In nonprofit sector, there is a hidden competition. However, those non-profit organizations which value brand orientation can be considered as the ones who are aware of the competition and want to gain a strong competitive position in the sector.

Hankinson (2000) suggests that brand orientation is related with the mindset and the style of management. In organizations that value branding, the brand is the focal of the organization. It is also mentioned by her that "to fulfill organizational objectives such as raising awareness, building trust, fundraising and parliamentary lobbying, with a more focused and more consistent communication of what the organization stand for" is easier for brand oriented non-profit organizations. Hankinson's suggestions support Aaker (1996) who posits that "the ideology of brand orientation needs to be transformed into action, which is marketing implementation".

Urde (1999) defines brand orientation as "an approach in which the processes of the organization revolve around the creation, development, and protection of brand identity in an ongoing interaction with target customers with the aim of achieving lasting competitive advantages in the form of brands." A brand oriented nonprofit organization pertains to creating value that satisfies the needy.

Hankinson (2000) in her study posited how charity brand could be built. She listed the tools that managers should benefit from to build charity brand as:

$\begin{array}{ll}\text { Visual communicators } & \text { Web sites } \\ \text { Media coverage } & \text { Slogan } \\ \text { Charity shops } & \text { Being professional }\end{array}$

Printed documents

Although there are several researches about brand orientation in the context of nonprofit sector, it needs further studies which will capture how it applies to this sector. While some researchers stand against the idea of applying marketing principles in this sector, it is obvious that it would resist to the practicality of marketing almost in many domains.

\subsection{Proposed Brand Orientation Model}

Based on the literature review, the model in the figure that could be used to measure brand orientation, antecedents, and performance outcomes in the nonprofit organizations is proposed (Hankinson, 2001a; Napoli, 2006; Candler \& Dumont, 2010).

\subsubsection{Antecedents of Brand Orientation}

Hankinson (2001a) provided the factors that could be accepted as the antecedents of brand orientation. They are personal vision of managers, relevant educational and job experience of managers with brand, a supportive organizational culture, and environmental factors that may influence organizational objectives. However, her suggestion about the antecedents seems not to be elaborate. Because while some of the factors she mentioned are related with the managers, some are related with the environment. However, environmental factors work different from factors related with management. Another weakness is that she does not differentiate internal and external factors, which might function separately. Moreover, she does not refer to the managers' characteristics sufficiently. So it is suggested that the antecedents should be personal vision of the managers, relevant educational and job experience of managers with brand, communication skills of the managers, and ability to develop positive relationships with the stakeholders.

The organization specific factors such as structure, culture, resources, type of the nonprofit organization, are also influential on management decisions. Thus, these factors should be considered as moderators between brand orientation and managers' characteristics. In this respect, Hankinson's model (2001a) falls short to discriminate main factors effective on brand orientation and managers' characteristics. A supportive organizational culture and environmental factors should be considered as mediators in the model, in that if the culture does not support the brand orientation within an organization, in which many stakeholders are more influential compared to for-profit organizations, managers could not succeed in developing a brand orientation culture. It is apparent that nonprofit organizations resources are mainly received from the donors and other stakeholders which have high impact on the organization. "Stakeholders of nonprofit organizations mainly include government agencies, donors, volunteers, beneficiaries, politicians, trustees, program managers, employees, funding bodies, and etc." (Bennett \& Savani, 2004). They implement a kind of pressure on the managers and their decisions, which affects 
managers to a great extend. Thus, the mediators should be the external environment the nonprofit organization is operating in and internal environment of the nonprofit organization.

\subsubsection{Brand Orientation}

I stick to the conceptual framework of brand orientation developed by Napoli (2006). In the model Napoli (2006) mentions three dimensions of brand orientation and operationalizes them successfully. The scale she used gave satisfactory results in terms of reliability and validity. "The first dimension, orchestration, evaluates an organization's capability to implement integrated marketing activities that deliver consistent brand messages to the stakeholders (both internal and external) and improve a brand portfolio that is understood by personnel. The second dimension called interaction measures the degree to which an organization utilizes market feedback to develop and deliver superior value to stakeholders of the organization." However, it should not be overseen that nonprofit organizations like for-profit organizations should consider the interests of foremost stakeholders without damaging the core brand identity (Hankinson 2001a). The "interaction dimension" indicates an organization's ability to respond to changing environment conditions and societies' needs and the ability of the organization to deliver value added services and products to their stakeholders. Satisfaction of stakeholder expectations results from an organization's ability "to generate market intelligence, disseminate information to relevant organizational members and then use them to develop services and products". This dimension is an indicator of a nonprofit organization's ability to perceive stakeholders' brand attitudes and feelings successfully (Ewing and Napoli, 2005).

\subsubsection{Outcomes of Brand Orientation in Nonprofit Sector}

Wong and Merrilees (1995) argue that implementing well-designed brand-oriented strategy provides the organizations with better outcomes. Brand-oriented strategy generates distinct brand values and these values might provide nonprofit organizations a good framework for planning and a guide for the strategies to be developed. Organizations taking the brand the basis of corporate strategy devote themselves to develop and support values within organization in line with their mission and vision.

In the literature, confusion seems apparent among the researchers searching performance results of nonprofit organizations. Prior researches have been listed in Table 1. It is really a complicated issue as it is still not clear how it should be measured. Unlike for-profit firms, the nonprofit organizations' output is vague and mostly difficult to observe. This topic should receive more interest from the researchers because nonprofit organizations image within the society depends on the opinion of the stakeholders about the outcomes of the nonprofit organizations. Moreover, governments, a main funder for nonprofit organizations, scrutinize their activities and put a great deal of the pressure on nonprofit sector in case it is believed that non-profit organizations are not using the public resources efficiently and effectively (Poole, 2000). In essence, their survival depends on resources they obtain from the stakeholders for whom trust and thus accountability defined as "the duty to give an account" (Schafer, 1999) is significant. Donors question achievement of non-profit organizations some of which might not be evaluated easily. Thus, the outcomes of non-profit organizations should be measured and reported in way that will help the stakeholders' evaluation. This will also provide transparency which will increase trust to the organizations.

The dimensions of performance were taken from Chandler and Dumont's (2010), but they are not enough to explain the comprehensive performance result of nonprofit organizations. These dimensions are goods and services, social capital, and policy impact. In addition to these, reputation and resource acquisition are included as two other dimensions. While finances and voluntary contribution are the key resource inputs for non-profit organizations, the goods and/or services produced are the key output, which indicates how efficient they are. Cutt (1982) argues that "efficiency in the absolute sense is the only complete measure of consequential accountability - for performance in the use of scarce resources - since it addresses whether or not the program in question is worth undertaking". Social capital - the impact an organization has on the community in which it operates - is the second key output included in this framework. It is "a systematic analysis of the effects of an organization on its communities of interest or stakeholders" (Quarter et. al., 2003). Raising awareness for social issues, educating the people how to overcome or deal with such issues all contribute to the social capital. Policy impact is another dimension in the model. Chandler \& Dumont (2010) suggest "the significant role of policy advocacy among a significant portion of non-profit organizations, assessing the policy impact of advocacy non-profits becomes a third important output of non-profit organizations." This dimension is relevant because one of the roles of the nonprofit organizations within a society is forcing the governments to act and make laws in favor of the social issues that have been neglected. 
Reputation is the forth dimension of performance of nonprofit organizations. Reputation is defined "an impression of esteem or high regard judged by others" (Merriam Webster's Collegiate Dictionary, 1996). Brand orientation enhances reputation of the nonprofit organizations, which means it creates positive associations within the minds of people. This will affect the contribution level of stakeholders to the organization, which indicates that it is an output to be measured in this model. Resource acquisition is the final performance dimension in the model. While the for-profit organizations earn revenue as a result of their activities as a reward, it is highly important for non-profit organization to receive donations and funds from the stakeholders. This will provide them to accomplish their missions, so it should be considered as a performance output as well.

\section{Contribution}

The constructs in the model have not previously been well defined in the literature, so this paper makes a conceptual contribution by establishing a framework about the researched concepts in this paper. Another contribution of the paper is that it proposes a model (Figure) integrating all the constructs in one study in the nonprofit sector and suggesting the relationships among them. This model is believed to a base for future quantitative researches that might test the relationships among the constructs mentioned. To a certain extent, this study supports the literature that brand orientation might play a significant role in developing nonprofit organizations' activities and structures. The study also shows the relevance of branding to nonprofit organizations.

\section{Conclusion}

In summary, a model of nonprofit brand orientation has been proposed in this literature review. Brand orientation, antecedents of brand orientation, mediators, and performance outcomes are critical to the development of the model proposed. Previous studies mainly focused on just brand orientation or brand orientation and performance results together. None of them tested all of the constructs mentioned in this model in the same framework. The proposed nonprofit brand orientation model in this paper will be a conceptual contribution to the branding literature, in that it is more comprehensive, it realizes the effects of mediators, and it proposes to use much comprehensive performance indicators. The main aim of the study was to use these constructs to provide a model and consequences of evolution of brand orientation in nonprofit sector which requires so many researches not just in terms of brand orientation but other marketing concepts as well. The model proposes that performance will be greater for nonprofit organizations pursuing an integrated brand orientation approach. However, empirical researches need to be varied out examined to test the fit of the model.

\section{References}

Aaker, D.A. (1991). Managing brand equity: Capitalizing on the value of a brand name. New York: Free Press.

Aaker, D.A. (1996). Measuring Brand Equity Across Products and Markets. California Management Review, 38(3), 112.

Aaker, D.A. \& Keller, K.L. (1990). Consumer Evaluations of Brand Extension. Journal of Marketing, 54(1), 27-43. doi:10.2307/1252171, http://dx.doi.org/10.2307/1252171

Arnold, M. J., \& Tapp, S. R. (2003). Direct Marketing in Non-profit Services: Investigating the Case of the Arts Industry. Journal of Services Marketing, 17(2), 141-160. doi:10.1108/08876040310467916, http://dx.doi.org/10.1108/08876040310467916

Balabanis, G., Stables, R.E., \& Phillips, H. C. (1997). Market Orientation in the Top 200 British Charity Organizations and Its impact on Their Performance. European Journal of Marketing, 31(8), 583-603. doi:10.1108/03090569710176592, http://dx.doi.org/10.1108/03090569710176592

Bennett, R. \& Sargeant A. (2005). Special Section: The Nonprofit Marketing Landscape. Journal of Business Research, 58, 797-805. doi:10.1016/j.jbusres.2003.12.001, http://dx.doi.org/10.1016/j.jbusres.2003.12.001

Bennett, R. \& Savani, S. (2004). Managing Conflict between Marketing and Other Functions within Charitable Organizations. Leadership and Organization Development Journal, 25(2), 180-200. doi:10.1108/1437730410521840, http://dx.doi.org/10.1108/1437730410521840

Candler, G. \& Dumont, G. (2010). A Non-profit Accountability Framework. Canadian Public Administration. 53(2), 259-279. doi:10.1111/j.1754-7121.2010.00126.x, http://dx.doi.org/10.1111/j.1754-7121.2010.00126.x

Chan, R.Y. \& Chau, A. (1998). Do Marketing-Oriented Children and Youth Centers (CYCs) Perform Better: An Exploratory Study in Hong Kong? Journal of Professional Services Marketing, 17(1), 15-28. doi:10.1300/J090v17n01_02, http://dx.doi.org/10.1300/J090v17n01_02 
Clarksona, P., Daviesa, S., Challisa, D., Donnellyb, M., \& Beechc, R. (2009). Has Social Care Performance in England improved? An Analysis of Performance Ratings Across Social Services Organizations. Policy Studies, 30(4), 403-422. doi:10.1080/01442870902899848, http://dx.doi.org/10.1080/01442870902899848

Cutt, J. (1982). Accountability, Efficiency, and the "Bottom Line" in Non-profit Organizations. Canadian Public Administration, 25(3), 311-31. doi:10.1111/j.1754-7121.1982.tb02078.x, http://dx.doi.org/ 10.1111/j.1754-7121.1982.tb02078.x

Dolnicar, S. \& Randle, M. (2007). What Motivates Which Volunteers? Psychographic Heterogeneity among Volunteers in Australia. Voluntas, 18:135-155. doi:10.1007/s11266-007-9037-5, http://dx.doi.org/10.1007/s11266-007-9037-5

Duque-Zuluaga L.C. \& Schneider, U. (2008). Market Orientation and Organizational Performance in the Nonprofit Context: Exploring Both Concepts and the Relationship Between Them. Journal of Nonprofit and Public Sector Marketing, 19(2), 25-47. doi: 10.130O/JO54V19nO2_O2, http://dx.doi.org/10.130O/JO54V19nO2_O2.

Ewing, M.T. \& Napoli, J. (2005). Developing and Validating a Multidimensional Nonprofit Brand Orientation Scale. Journal of Business Research, 58(6), 841-853. doi:10.1016/j.jbusres.2003.09.012, http://dx.doi.org/10.1016/j.jbusres.2003.09.012

Gainer, B. \& Padanyi, P. (2002). Applying the Marketing Concept to Cultural Organizations: An Empirical Study of the Relationship between Market Orientation and Performance. International Journal of Nonprofit and Voluntary Sector Marketing, 7(2), 182-193. doi:10.1002/nvsm.178, http://dx.doi.org/10.1002/nvsm.178

Hankinson, P. (2000). Brand Orientation in Charity Organizations: Qualitative Research into Key Charity Sectors. International Journal of Nonprofit and Voluntary Sector Marketing, 5(3), 207-219. doi:10.1002/nvsm.114, http://dx.doi.org/10.1002/nvsm.114

Hankinson, P. (2001a). Brand Orientation in the Charity Sector: A Framework for Discussion and Research. International Journal of Nonprofit and Voluntary Sector Marketing, 6(3), 231-242. doi:10.1002/nvsm.149, http://dx.doi.org/10.1002/nvsm.149

Hankinson, P. (2001b). Brand Orientation in the Top 500 Fundraising Charities in the UK. Journal of Product \& Brand Management, 10(6), 346-360. doi:10.1108/10610420110406040, http://dx.doi.org/10.1108/10610420110406040

Hassay, D.N. \& Peloza, J. (2009). Building the Charity Brand Community. Journal of Nonprofit \& Public Sector Marketing, 21, 24-55. doi: 10.1080/10495140802111927, http://dx.doi.org/10.1080/10495140802111927

Hibbert, S. A. \& Horne, S. (1995). Donation Dilemmas: A Consumer Behavior Perspective. International Journal of Nonprofit and Voluntary Sector Marketing, 2(3), 261-274. doi:10.1002/nvsm.6090020308, doi:10.1002/nvsm.6090020308

Hou, J., Du, L., \& Tian, Z. (2009). The Effects of Nonprofit Brand Equity on Individual Giving Intention: Mediating by the Selfconcept of Individual Donor. International Journal of Nonprofit and Voluntary Sector Marketing, 14, 215-229. doi:10.1002/nvsm.356, http://dx.doi.org/10.1002/nvsm.356

Jacobs, R.N. \& Glass, D.J. (2002). Media Publicity and the Voluntary Sector: The Case of Nonprofit Organizations in New York City. Voluntas: International Journal of Voluntary and Nonprofit Organizations, 13(3), 235-252. doi:10.1023/A:1020337425782, http://dx.doi.org/10.1023/A:1020337425782

Kara, A., Spillan, J.E., \& DeShields, O.W. Jr. (2004). An Empirical Investigation of the Link between Market Orientation and Business Performance in Non-Profit Service Providers. Journal of Marketing Theory-and Practice, 12(2), 59-72.

Keller, K.L. (2003). Strategic brand management: Building, measuring and managing brand equity, (2nd ed.). Englewood Cliffs, NJ: Prentice-Hall.

Liao, M.N., Foreman, S., \& Sargeant, A. (2001). Market versus Societal Orientation in the Nonprofit Context. International Journal of Nonprofit and Voluntary Sector Marketing, 6(3), 260. doi:10.1002/nvsm.151, http://dx.doi.org/10.1002/nvsm.151

Laidler-Kylander, N. \& Simonin, B. (2009). How International Nonprofits Build Brand Equity. International Journal of Nonprofit and Voluntary Sector Marketing, 14, 57-69. doi:10.1002/nvsm.353, http://dx.doi.org/10.1002/nvsm.353

Merriam Webster's Collegiate Dictionary. (1996). (10th ed.). Springfield, MA: Merriam Webster, Inc. 
Napoli, J. (2006). The Impact of Nonprofit Brand Orientation on Organizational Performance. Journal of Marketing Management, 22, 673-694. doi:10.1362/026725706778612176, http://dx.doi.org/10.1362/026725706778612176

Poole, D.L., Nelson, J., Carnahan, S., Chepenik, N.G., \& Tubiak, C. (2000). Evaluating Performance Measurement Systems in Nonprofit Agencies: The Program Accountability Quality Scale (PAQS). American Journal of Evaluation, 21(1), 15-26. doi:10.1177/109821400002100102, http://dx.doi.org/10.1177/109821400002100102

Quarter, J., Mook, L., \& Richmond, B. (2003). What Counts: Social Accounting for Nonprofits and Cooperatives. Englewood Cliffs, N.J.: Prentice Hall.

Schafer, A. (1999). A Wink and a Nod: A Conceptual Map of Responsibility and Accountability in Bureaucratic Organizations. Canadian Public Administration, 42(1), 5-25. doi:10.1111/j.1754-7121.1999.tb01545.x, http://dx.doi.org/10.1111/j.1754-7121.1999.tb01545.x

Urde, M. (1994). Brand Orientation-A Strategy for Survival. The Journal of Consumer Marketing, 11(3), 18-33. doi:10.1108/07363769410065445, http://dx.doi.org/10.1108/07363769410065445

Urde, M. (1999). Brand Orientation: A Mindset for Building Brands into Strategic Resources. Journal of Marketing Management, 15, 117-133. doi:10.1362/026725799784870504, http://dx.doi.org/10.1362/026725799784870504

Voeth, M. \& Herbst, U. (2008). The Concept of Brand Personality as an Instrument for Advanced Non-Profit Branding- An Empirical Analysis. Journal of Nonprofit \& Public Sector Marketing, 19(1), 71-97. doi:10.I300/J054v19n01 04, http://dx.doi.org/10.I300/J054v19n01 04

Voss, G.B. \& Voss, Z.G. (2000). Strategic Orientation and Firm Performance in an Artistic Environment. Journal of Marketing, 64(1), 67-83. doi:10.1509/jmkg.64.1.67.I7993, http://dx.doi.org/10.1509/jmkg.64.1.67.I7993

Wiepking, P. (2007). The Philanthropic Poor: In Search of Explanations for the Relative Generosity of Lower Income Households. Voluntas, 18, 339-358. doi:10.1007/s11266-007-9049-1, http://dx.doi.org/10.1007/s11266-007-9049-1

Wong, H.Y. \& Merrilees, B. (2005). A Brand Orientation Typology for SMEs: A Case Research Approach. Journal of Product \& Brand Management, 14(3), 155-162. doi:10.1108/10610420510601021, http://dx.doi.org/10.1108/10610420510601021

Table 1. Review of the Literature on Organizational Performance in NPOs

\begin{tabular}{|c|c|}
\hline Study & Performance measurements \\
\hline $\begin{array}{l}\text { Balabanis, Stables \& Phillips (1997) } \\
200 \text { British Charity organizations }\end{array}$ & $\begin{array}{l}\text { Achievement of short-term objectives } \\
\text { Achievement of long-term objectives } \\
\text { Expenses to donor contribution ratio } \\
\text { Variation in ratio } \\
\text { Number of volunteers } \\
\text { Variation in volunteers }\end{array}$ \\
\hline $\begin{array}{l}\text { Chan \& Chau (1998) } \\
\text { Children and youth centers at Hong } \\
\text { Kong }\end{array}$ & $\begin{array}{l}\text { Overall satisfaction } \\
\text { Members currently registered in the center } \\
\text { Financial subsidy received } \\
\text { Number of paid staff }\end{array}$ \\
\hline $\begin{array}{l}\text { Voss \& Voss (2000) } \\
\text { U.S. Nonprofit theaters }\end{array}$ & $\begin{array}{l}\text { Managers' perceptions of subscription sales, single } \\
\text { ticket sales, and financial performance compared to } \\
\text { peer organs } \\
\text { Subscriber attendance } \\
\text { Single ticket attendance } \\
\text { Total income } \\
\text { Net surplus/deficit }\end{array}$ \\
\hline $\begin{array}{l}\text { Gainer \& Padanyi (2002) } \\
\text { Canadian art and culture } \\
\text { organizations }\end{array}$ & $\begin{array}{l}\text { Managers' perceptions of customer satisfaction. } \\
\text { Resource acquisition and } \\
\text { Reputation among sector peers compared to five } \\
\text { years ago }\end{array}$ \\
\hline $\begin{array}{l}\text { Kara, Spillan \& DeShields (2004) } \\
\text { Diverse NPOs across the U.S. }\end{array}$ & $\begin{array}{l}\text { Fundraising performance derived from } 3 \text { measures: } \\
\text { continuous analysis of funding }\end{array}$ \\
\hline
\end{tabular}




\begin{tabular}{|c|c|}
\hline & $\begin{array}{l}\text { proposal to funding sources } \\
\text { periodic fundraising }\end{array}$ \\
\hline $\begin{array}{l}\text { Padanyi \& Gainer (2004) } \\
\text { Social services, arts and culture and } \\
\text { community support subsectors in } \\
\text { Canada }\end{array}$ & $\begin{array}{l}\text { Clients:(same factors as in Gainer \& Padanyi, 2002) } \\
\text { Government funders } \\
\text { Growth in resources } \\
\text { Growth in reputation }\end{array}$ \\
\hline \multicolumn{2}{|l|}{ Source: Duque-Zuluaga (2008) } \\
\hline $\begin{array}{l}\text { Hankinson (2001) } \\
\text { Brand orientation in charity sector }\end{array}$ & $\begin{array}{l}\text { Developing a strong brand } \\
\text { Successful fulfillment of organizational objective } \\
\text { Inclusive organizational culture }\end{array}$ \\
\hline $\begin{array}{l}\text { Arnold \& Tapp (2003) } \\
\text { Nonprofit in art industry }\end{array}$ & $\begin{array}{l}\text { Sales performance } \\
\text { Fundraising performance } \\
\text { Season-ticket revenue as a percentage of total } \\
\text { revenue }\end{array}$ \\
\hline $\begin{array}{l}\text { Griggs (2003) } \\
\text { Strategic planning in disabled-based } \\
\text { nonprofit organizations }\end{array}$ & $\begin{array}{l}\text { Index of organizational effectiveness (Mott, 1972) } \\
\text { Productivity } \\
\text { Adaptability } \\
\text { Flexibility }\end{array}$ \\
\hline $\begin{array}{l}\text { Seymour et. al. (2006) } \\
\text { Market orientation in charities }\end{array}$ & Same as Balabanis and Stables (1997) \\
\hline $\begin{array}{l}\text { Napoli (2006) } \\
\text { Brand orientation and performance }\end{array}$ & $\begin{array}{l}\text { Achieving short term objectives } \\
\text { Achieving long term objective }\end{array}$ \\
\hline $\begin{array}{l}\text { Poole et. al. (2006) } \\
\text { Performance measurement systems } \\
\text { in nonprofit organizations }\end{array}$ & $\begin{array}{l}\text { Resources, Activities, Outputs, Outcomes, Goals, } \\
\text { Indicators, Evaluation program }\end{array}$ \\
\hline $\begin{array}{l}\text { Duque-Zuluaga (2008) } \\
\text { Market orientation and performance }\end{array}$ & $\begin{array}{l}\text { Beneficiary or recipient response } \\
\text { Financial flexibility and resource acquisition } \\
\text { Volunteer and employee satisfaction } \\
\text { Responsiveness assessment } \\
\text { Long-term outcomes } \\
\text { Program outputs and intermediate term outcomes } \\
\text { Organizational efficiency }\end{array}$ \\
\hline $\begin{array}{l}\text { Clarkson et. al. (2009) } \\
\text { Social service organizations }\end{array}$ & summary measures ('star' ratings) \\
\hline $\begin{array}{l}\text { Candler \& Dumont, } 2010 \\
\text { Nonprofit accountability }\end{array}$ & $\begin{array}{l}\text { Goods and services } \\
\text { Policy impact } \\
\text { Social capital }\end{array}$ \\
\hline
\end{tabular}

\begin{tabular}{|c|c|c|}
\hline $\begin{array}{l}\text { Antecedent } \\
\text { Personal vision of managers } \\
\text { Relevant education and job } \\
\text { experience of managers } \\
\text { with brand } \\
\text { Personal skills }\end{array}$ & $\begin{array}{l}\text { Brand Orientation } \\
\text { Orchestration } \\
\quad \text { (integrated marketing activities) } \\
\text { Interaction } \\
\quad \text { (using market feedback and creating value) } \\
\text { Affect } \\
\quad \text { (understanding the stakeholders' attitudes } \\
\text { and feelings about the brand) }\end{array}$ & $\begin{array}{l}\text { Performance Outcomes } \\
\text { Goods and services } \\
\text { Policy impact } \\
\text { Social capital } \\
\text { Resource acquisition } \\
\text { Reputation }\end{array}$ \\
\hline $\begin{array}{l}\text { Moderatc } \\
\text { Internal e } \\
\text { External }\end{array}$ & $\begin{array}{l}\text { nment } \\
\text { onment }\end{array}$ & \\
\hline
\end{tabular}

Figure 1. Proposed Model 